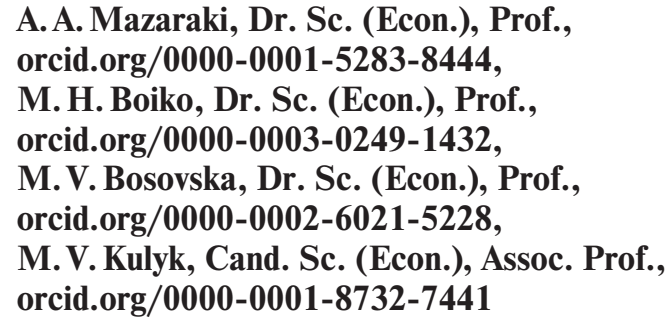

\title{
MULTI-AGENT INFORMATION SERVICE SYSTEM OF MANAGING INTEGRATION PROCESSES OF ENTERPRISES
}

Purpose. To model consolidated information systems as a result of interaction of economic entities in the information space. To reveal the information and communication direction of the virtual integration plane, to substantiate the principles of its formation and composition of the elements which constitute it.

Methodology. The theoretical and methodological basis of the article involves neoclassical economic theories, concepts of economic integration, methodological basis of systematic and synergistic approaches. The authors used methods of subject and cognitive modeling, which allowed developing a model of multi-agent information plane to implement mechanisms of interaction of participants in integrated business structures. The logical method of scientific cognition allowed the authors to formulate conclusions that substantiate the need to create an economic and informational space for interaction between the participants of the economic integration.

Findings. The authors suggest the theoretical and methodological provisions of the use of information technologies to ensure the information interaction of participants of integration entities. A model of a multi-agent information plane, based on a 4-tier open distribution information system, is presented. The role and tasks of interconnected subsystems in the economic and information space are substantiated. Directions of influence through the formed information and communication corridors are clarified. The authors proved the need to accumulate information flows within the virtual integration plane based on the agents' local information systems. The multi-agent architecture of the virtual interaction environment for business entities within the integration plane is improved; the scheme of virtual agent interaction model based on the virtual plane is defined and the block diagram of the algorithm of interaction of economic agents within the virtual integration plane is improved.

Originality. Scientific priority of ensuring information interaction of participants of integration entities based on using information technologies is enhanced. The authors revealed information and communication direction of the virtual integration plane. The process of formation of the virtual economic-information space of interaction of participants within the framework of a multiagent virtual information plane is specified, which allows accumulating, processing, distributing, and using the consolidated knowledge base with the purpose of information and communication support of cross-cutting business processes, support of the adoption of management decisions to provide virtual interaction of the agents.

Practical value. The conducted research provides applied tools of modernization of the use of information technologies to ensure information interaction of participants of integration entities. A virtual integration plane is formed, which is the basis for managing the virtual integration interaction of business entities and implementing the concept of integration development. The results obtained during the research will allow providing informational support of managerial decision-making, implementing economic ties, monitoring the implementation of integration programs and strategies.

Keywords: information systems, integration development, business entities

Introduction. In the conditions of formation of the information society, the mechanisms of interaction of economic entities are transformed, which is accompanied by an increasing role of information as a consolidated resource, intensive use of the global information space and information systems as a communication medium of interaction. This leads to the transfer of a significant amount of connection and interaction of economic agents in the information space, accompanied by the need to deepen the use of information technology, the creation of consolidated information systems and actualize the need for the formation of effective mechanisms for the implementation of virtual information interaction.

Literature review. The prerequisites for forming conclusions about the peculiarities of forming a consolidated information space of interaction of participants of integration processes are determined both by the tendencies of structural transformations in the economy, as well as by the nature of internal motives and factors of economic entities that encourage them to inform interaction. Theoretical and methodological understanding of the problem of development of information support for integration processes at different hierarchical levels of the economic system, made it possible to conclude that there is no clear methodological justification of approach-

(C) Mazaraki A.A., Boiko M.H., Bosovska M.V., Kulyk M.V., 2020 es to the formation of a consolidated information system that allows realizing economic information interaction.

Thus, Okunlola, O.A., Masade, E. O., Lukman, A. F., Abiodun, S.A. (2020) identified the possibility of consolidation of information as the main motive for the relationship between financial development and economic growth and integration [1]. Korn, O., Schmidt, A. considered the need to acquire new knowledge and to form consolidated information systems for the use to "gamify" business processes [2].

Davidavicienè, V., Allelūnas, I., Sabajite, I. (2015) noted that information and communication technologies have a decisive influence on the competitiveness of the organization [3].

Ajibade, P., Ondari-Okemwa, E. M. and Matlhako, M. (2019) formulated the basic requirements and identified the necessity of information technology use as strategic tool to promote business decision making through quick business data analysis and dissemination of business ideas across business units and locations [4].

Petrasch R. (2020) proposed to solve the faults in traditional control algorithm and achieve the goal of improvement; a new statistical process control approach is proposed to global optimization of system integration. They proposed comprises various tasks such as providing the strategies, concepts, infrastructure, and tools for OLTP (Online Transaction Processing) and OLAP (On-line Analytical Processing) [5]. 
Heimburger L., Buchweitz L., Gouveia R., Korn O. (2020) analyzed Software tools and especially mobile applications as innovative means to support providing onboarding processes in a modern, even remote, way, described a mobile onboarding application specifically developed for the young, technically literate generations $Y$ and $Z$, who are just about to start their career [6].

Particularly noteworthy are the studies by Nissen, V., Füßl, A., Werth, D., Gugler, K., Neu, C. (2019) and Genc, T. S., De Giovanni, P. (2020), who examined methods for the selection and implementation of information technology in the digital transformation era, analyzed the current status and future developments of the digital transformation in business consulting $[7,8]$.

Abtahi, A.-R., Abdi, F. (2018) investigated the information interaction of participants using effective mechanisms for monitoring process, using cloud computing as an approach to access the virtualized resources based on an integrated system [9].

Heidari, M. R., Heravi, G., Esmaeeli, A. N. (2020) detail a comprehensive step-by-step approach to building a best practice-driven, multi-year roadmap in the quest for architecturally evolvable BI and data warehousing at the enterprise scale. The authors addressed the sustainable development which requires decision-making systems based on sustainability criteria and overpassing just economic and financial criteria. Integration of life-cycle cost analysis (LCCA) and life-cycle assessment (LCA) to select pavement alternative is a solution to address economic and environmental issues simultaneously [10].

Korn, O., Funk, M., Schmidt, A. (2015) presented gamification as an ever more popular method to increase motivation and user experience in real-world settings. It is widely used in the areas of marketing, health and education. The authors proposed a new concept for participants of integration entities in production environments, accepted in the industrial domain; it has to be seamlessly integrated in the regular work processes [11].

Bressanelli, G., Perona, M., Saccani, N. (2019) in the paper "Challenges in supply chain redesign for the Circular Economy: a literature review and a multiple case study" identify and systematize 24 challenges that may hamper a supply chain redesign for the Circular Economy [12].

Results. To ensure information interaction of participants of integration entities, which will allow carrying out information support of management decisions, virtually realizing economic ties, monitoring the implementation of integration programs and strategies, the creation of an economic and informational space of interaction of information integrators and tools implementation of integration interaction is required.

Economic-information space of interaction of the participants of integration is a subsystem of external global information infrastructure and allows realizing economic information interaction of economic subjects. This layer is characterized by indicators of completeness of information, reliability, sufficiency, which create information "visibility" of the agent in relation to other economic entities and contribute to its integration activity. Business entities implement this level of integration processes on a global distribution systems platform. Having passed the sensory level, the subjects engage in economic interaction within a single information and communication virtual plane. Entrepreneurs are implementing business processes and integrated information systems on the platform of the product family $1 \mathrm{C}$, etc., which are used as mechanisms for implementing virtual integration interaction.

The third level of the integrated information plane creates an additional information contour, which aggregates information flows coming from the first level, which allows accumulating knowledge in the distribution base of knowledge of integrated entities and transferring it for management decisions in strategic centers of the integrated structures.
Multi-agent virtual information plane is a consolidated information and communication system that allows implementing mechanisms of interaction of economic agents (participants of integration processes) in the economic-information space and accumulating, processing, distributing, using consolidated information for the purpose of informational support of decision making concept of integration development.

Fig. 1 presents a model of a multi-agent information plane, which is based on a 4-tier open distribution information system. The architecture of this system is formed from 4 levels: touch (a set of information); implementation (distribution information system, which allows for information interaction based on the use of information); cognitive (knowledge distributive framework that allows knowledge to be accumulated and transmitted to actors for management decisions); personified (individual actor knowledge base, local information system).

At the top level of the proposed architectural design, information is exchanged between economic entities regarding the realization of the interaction possibilities. This level is formed on the basis of publicly available information contained on websites, regional and industry portals, reference sources.

As information accumulated by actors in the economic information space is part of the information support for strategic management decision making, the virtual plane is accordingly integrated into the decision support system. The architecture of the specified segment is a collection of the following interconnected subsystems:

- accumulation of information from external sources;

- monitoring of indicators of socio-economic development of industry, region, economic entities;

- modeling the development of an integrated structure (interaction of economic agents), forecasting scenarios for the development of relationships between agents within the integrated formation;

- formation of document flow (incoming, outgoing, regulatory and other documents).

In the process of virtual interaction between agents, a significant number of positive, negative, direct, indirect and feedbacks are formed, the implementation of which allows ex-

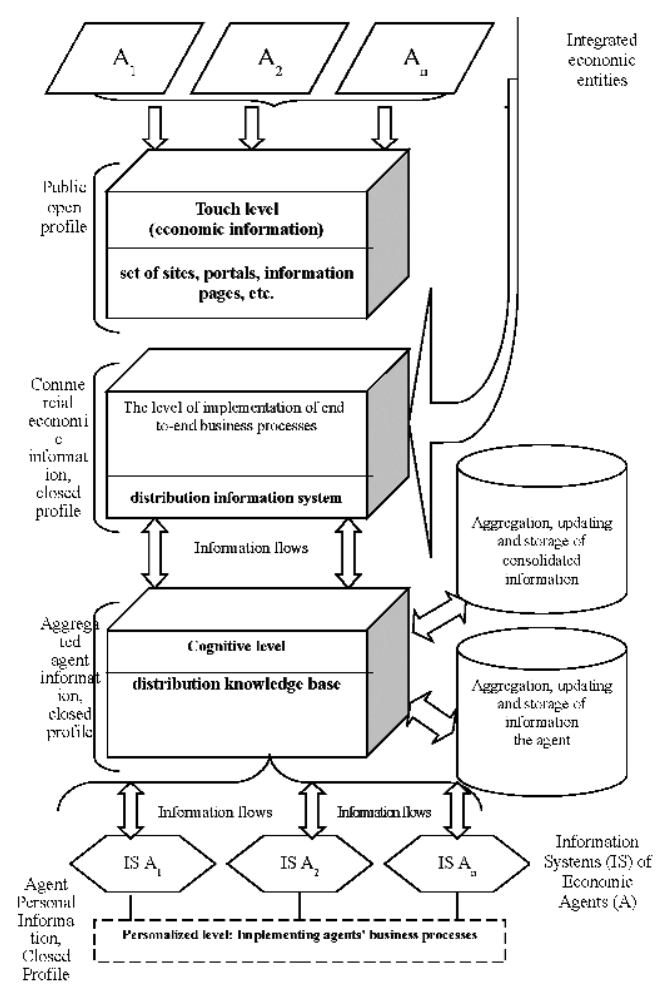

Fig. 1. Model of multi-agent integrated information space 
erting managerial influences through the formed information and communication corridors, which is presented in Table.

Within the virtual integration plane, information flows are accumulated on the basis of agents' local information systems (Level 4 of the multi-agent space profile - personalized), which are the source of both the formation of the sensory level of virtual interaction, and of the distributive and cognitive. For the technical implementation of this concept it is recommended to use specialized systems of KDD (Knowledge Discovery in Databases) Data Mining.

The multi-agent architecture of the virtual interaction environment for tourism entities within the integration plane has a dual purpose, which causes difficulties in its implementation. Thus, on the one hand, it aims to support managerial decision-making in the development of an integration strategy, which requires the generation of information about the possibility of growth of resource potential due to the creation of integration chains of interaction and the need for integration, which leads to reduced competition in the market. On the other hand, monitoring the implementation of the integration strategy requires determining the effectiveness of integration processes in terms of increasing resource potential.

Since, within the integration plane, diagnostics of interaction of economic agents is considered, which are considered as a decentralized system (each participant has individual target orientations, unique resource potential, certain behavior in the external environment), so in the process of information transformation the subjects of information space perceive information flows through individual filtration and information pro- cessing - mental models that provide a personal understanding of the environment and internal consumption and solving the management problems of each agent recorded in the form of information resources.

The mental model $\left(K_{A s i}\right)$ of the agent is defined as the projection of the agent's architecture on the level of business process realization (Fig. 2)

$$
K_{A s i}=f\left(A_{s i}^{E}, A_{s i}^{p}\right),
$$

where, $S_{i}$ is interacting entities; $A_{s i}^{E}, A_{s i}^{p}$ are the role of the agent at the time of the act of virtual interaction.

During the interaction, the subjects $S_{i}$ can play different roles and change them (initiator, receiver). At the same time, for the implementation of a separate act of interaction, agents are activated and implement a business process based on a basic information architecture $B_{1 i j}, B_{n i j}$ to create a cross-cutting business process, $n$ is the number of business processes that agents implement in a single act of interaction. The results of each business process are transmitted to the cognitive level of the virtual plane, with the attributes and parameters of the implementation of business processes which are private information and are the property of only those agents who have been involved in virtual interaction.

Some of the closed information is cognitively accumulated and transmitted for consolidated access by all participants in the virtual information environment. The main element of this interaction is the component $K B_{m i j}$ - a database of rules of virtual interaction (procedures for implementing the $m^{\text {th }}$ business process), which are the norms of the implications of the form.

Matrix of managing influences on interconnections and resource-functional orientation of information and communication corridors within the integrated virtual plane

\begin{tabular}{|c|c|c|c|c|c|c|c|c|c|c|}
\hline \multirow{2}{*}{\multicolumn{2}{|c|}{$\begin{array}{l}\text { Strategic guidelines } \\
\text { for ensuring effective } \\
\text { engagement }\end{array}$}} & \multirow{2}{*}{\multicolumn{4}{|c|}{$\begin{array}{l}\text { Relationships between agents within the formed information } \\
\text { and communication corridors }\end{array}$}} & \multicolumn{5}{|c|}{$\begin{array}{l}\text { The nature of the influence of the elements } \\
\text { of the outer shell of the virtual plane }\end{array}$} \\
\hline & & & & & & \multirow{2}{*}{$\begin{array}{c}\begin{array}{c}\text { Goal } \\
\text { Level }\end{array} \\
Z_{1}\end{array}$} & \multirow{2}{*}{$\begin{array}{c}\begin{array}{c}\text { Mega } \\
\text { Level }\end{array} \\
Z_{2}\end{array}$} & \multirow{2}{*}{$\begin{array}{c}\begin{array}{c}\text { Macro } \\
\text { Level }\end{array} \\
Z_{3}\end{array}$} & \multirow{2}{*}{$\begin{array}{c}\begin{array}{c}\text { Mezzo } \\
\text { Level }\end{array} \\
Z_{4}\end{array}$} & \multirow{2}{*}{$\begin{array}{r}\begin{array}{r}\text { Micro } \\
\text { Level }\end{array} \\
Z_{i i}\end{array}$} \\
\hline $\begin{array}{l}\text { Links between } \\
\text { subsystems }\end{array}$ & & $\overline{X_{1 \ldots i}}$ & $X_{2 \ldots i}$ & $X_{3 \ldots i}$ & $X_{4 \ldots i}$ & & & & & \\
\hline $\begin{array}{l}\text { Provision subsystem } \\
\text { (conditions for } \\
\text { formation, } \\
\text { allocation of } \\
\text { potential } \\
\text { utilization) }\end{array}$ & 1 & $\begin{array}{l}\text { Resource and } \\
\text { recreational } \\
\text { potential of } \\
\text { the region, } a_{11}\end{array}$ & $a_{12}$ & $a_{13}$ & $a_{1 i}$ & $\begin{array}{r}\beta_{11} \\
\\
\\
\\
y\end{array}$ & $\beta_{12}$ & $\beta_{13}$ & $\beta_{14}$ & $\beta_{1 i}$ \\
\hline $\begin{array}{l}\text { Regulation and audit } \\
\text { subsystem } \\
\text { (interaction } \\
\text { trajectories, change } \\
\text { parameters, impact } \\
\text { weight) }\end{array}$ & 2 & $a_{21}$ & $\begin{array}{c}\text { Agent } \\
\text { Information } \\
\text { Communication } \\
\text { System } a_{22}\end{array}$ & $\stackrel{a_{23}}{\longleftarrow}$ & $a_{2 i}$ & $\begin{array}{r}\beta_{21} \\
\\
\\
\end{array}$ & $\beta_{22}$ & $\begin{array}{ll}\beta_{23} & \\
& \\
& \\
& \end{array}$ & $\beta_{24}$ & $\beta_{2 i}$ \\
\hline $\begin{array}{l}\text { Transformation } \\
\text { subsystem (increase } \\
\text { in material and } \\
\text { intangible potential, } \\
\text { optimization of } \\
\text { business processes) }\end{array}$ & 3 & $a_{31}$ & $\begin{array}{l}a_{32} \\
\end{array}$ & $\begin{array}{c}\text { Economic, } \\
\text { environmental, } \\
\text { social, innovation } \\
\text { and investment } \\
\text { potential of } \\
\text { agents, } a_{33}\end{array}$ & $a_{3 i}$ & $\begin{array}{r}\beta_{31} \\
\quad \\
\\
\\
\quad \\
\end{array}$ & $\longleftarrow$ & $\beta_{33}$ & $\beta_{34}$ & $\beta_{3 i}$ \\
\hline $\begin{array}{l}\text { Forecasting } \\
\text { subsystem } \\
\text { (knowledge } \\
\text { generation, adaptive } \\
\text { management) }\end{array}$ & 4 & $a_{41}$ & $a_{42}$ & $a_{43}$ & $\begin{array}{l}\text { Organizational, } \\
\text { managerial, } \\
\text { intellectual } \\
\text { potential of the } \\
\text { integrated } \\
\text { structure, } a_{4 i}\end{array}$ & $\begin{array}{r}1 \\
+\quad 1 \\
\end{array}$ & $\begin{array}{r}\beta_{42} \\
\quad \\
\\
\quad \\
\\
\end{array}$ & $\begin{array}{r}\beta_{43} \\
\quad \\
\\
\quad \\
\quad \\
\end{array}$ & $\beta_{44}$ & $\beta_{4 i}$ \\
\hline
\end{tabular}

where, $X$ is communication corridors between agents; $a$ - the nature of the control effects; $Z$ - external influences and obstacles; $\beta-$ nature of

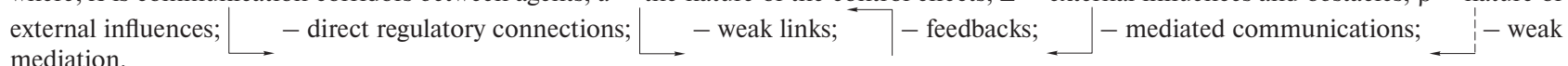




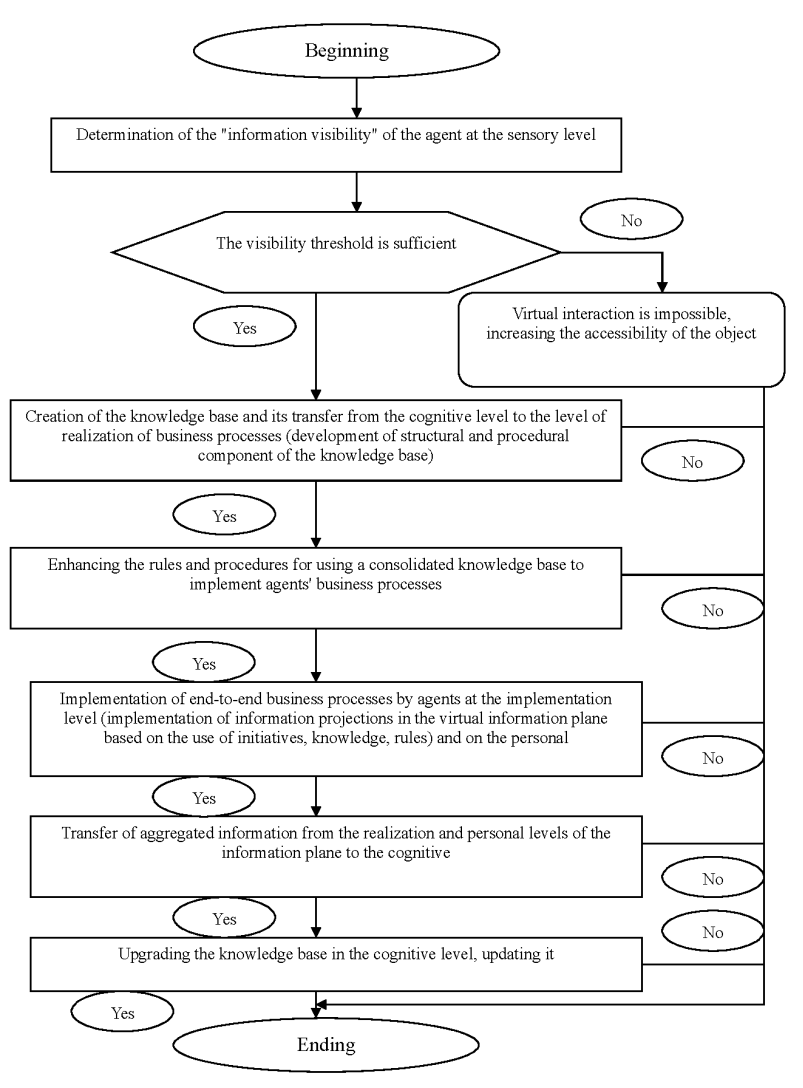

Fig. 2. Schematic of the virtual agent interaction model based on the virtual plane

$$
r_{m}\left(F_{1}\right) \wedge \ldots \wedge r_{m}\left(F_{i}\right) \wedge \ldots \wedge r_{m}\left(F_{i B m}\right) \rightarrow \rho_{m}\left(\Delta P_{j}\right),
$$

where $I_{B m}$ is the number of functions of the $m^{\text {th }}$ business process; $r_{m}\left(F_{i}\right) \in\{0,1\}$ is the fact of effective implementation of the $i^{\text {th }}$ function of the current business process (complete implementation of the business process according to the algorithm of the agent's behavior); $\rho_{m}\left(\Delta P_{j}\right)$ is assessment of the impact of the business process on the growth of the $j^{\text {th }}$ component of the resource potential of participants (determined on the basis of peer review by the criteria: 1 - negative increase in resource potential (loss, decrease); 0.5 - probability of negative growth; 0 - no change; 0.5 - probability of increase; $1-$ positive gain).

The obtained values characterize the results of the implementation of the acts of interaction, the accumulation of which makes it possible to determine the total increase in the resource potential of the agents. The algorithm of resource potential growth is built on the basis of additive reconciliation by potential criteria

$$
\begin{aligned}
& \operatorname{Sum}_{1 B i j}=\sum_{m}^{n}=1 \varnothing \rho_{m}\left(\Delta P_{1}\right) ; \\
& \operatorname{Sum}_{x B i j}=\sum_{m}^{n}=1 \varnothing \rho_{m}\left(\Delta P_{x}\right),
\end{aligned}
$$

where $\varnothing_{l m}, m=\overline{1, n} ; l=\overline{1, x}$ are business process weights from the point of view of growth of resource potential.

If $A c t_{S_{i} S_{j}}^{T}$ is an act of interaction of subjects $S_{i}$ and $S_{j}$ within the virtual information plane at a certain point in time $-T, T_{0}$ is the moment of time of the first interaction between these actors. The formed model of virtual interaction of actors within the virtual plane will allow estimating the effect of interaction from the point of view of growth of aggregate resource potential (consolidated knowledge base) for the period of time from $T_{0}$ to $T$

$$
\Omega\left(A_{c t}^{T i s j} \operatorname{siT}^{T}\right)=\left(\operatorname{Sum}_{1 B i j}, \operatorname{Sum}_{x B i j}\right) .
$$

In this case, the agent interaction environment is an economic-information multi-agent space (consolidated distribution system) and can be represented as a set of agents, each of which is an intellectual information subsystem, characterized by a set of goals, individual properties, rules of behavior and market behavior.

In the multi-agent environment of interaction of the subjects of tourism activity several determinant agents are identified - prototypes: enterprise-producer of tourist product; an enterprise agent, an enterprise operator, an investor, each of which has its own role in the value chain. In the processes of interaction, agents accumulate knowledge in their own knowledge bases, resulting in the process of adaptation of subjects to changes in the environment and the development of agents [13]. Each agent has the basic architecture and structure of the knowledge bank and can interact with another agent within the virtual integration plane, the mechanism of which is presented in Fig. 3.

In order to reach the targets of the participants of virtual interaction through the implementation of business processes, agents communicate with each other through requests and messages, which is preceded by their information visibility (availability and information space of sufficient and reliable information about the subject of the relationship), and perform specified actions and operations according to available knowledge. From the formed algorithm it is evident that in the process of interaction the cycle of knowledge exchange between levels of information plane of interaction is realized, at the expense of which the knowledge base of the cognitive level is kept up-to-date.

In this case, the architecture of interaction of participants of integration processes based on a multi-agent approach has a specific substantive and meaningful interpretation - the behavior of the agent (procedural component of the knowledge base) is given priority, and is formed in the process of implementation of the act of interaction by replenishing and updating the knowledge base at each moment of time. The purpose of virtual interaction management is to accumulate knowledge. In this case, each agent is not only a user of information, but also a source of knowledge and a means of their accumulation within the cognitive level.

Conclusions. The created virtual integration plane is the basis for managing the virtual integration interaction of economic entities in the business sector as an important mechanism for implementing the concept of integration development. A multi-agent virtual information plane defines a consolidated information and communication system that allows implementing mechanisms of interaction of economic agents

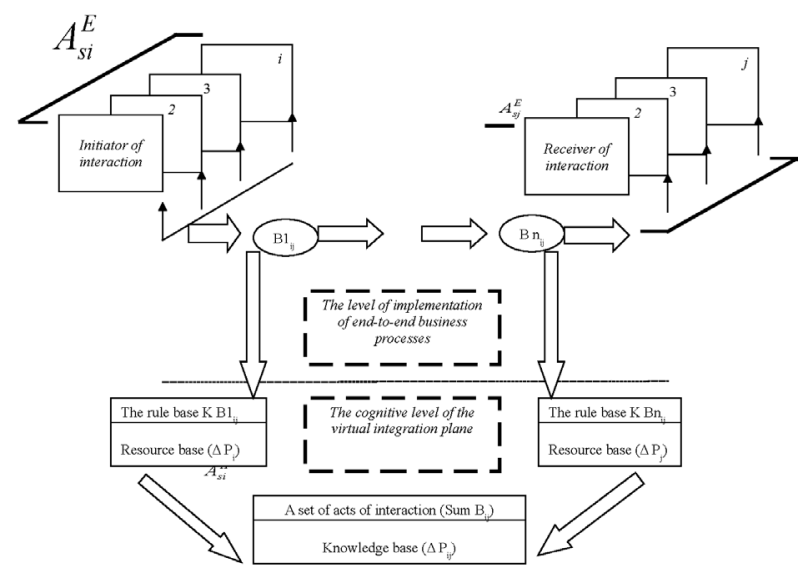

Fig. 3. Flowchart of the algorithm of interaction of economic agents within the virtual integration plane 
(participants of integration processes) in the economic information space through the accumulation, processing, distribution, use of consolidated information in order to support the conceptualization of decision making development. The architecture of the multi-agent information plane is presented in the context of four levels: the touch (a set of information); implementation (distribution information system, which allows for information interaction based on the use of information resources); cognitive (knowledge distributive framework that allows knowledge to be accumulated and passed on to actors for management decisions); personified (individual actor knowledge base, local information system). For realization of management influences within the integrated virtual plane, a matrix model of creation of information and communication corridors for interaction of participants on resource and functional orientation was formed. It is determined that the transformation of information by the subjects of the virtual information space occurs on the basis of individual filtering and processing of information - mental models, which are defined as the projection of the agent's architecture on the level of business process realization, ensure the management decisions by the agents based on the consolidated knowledge bases, recorded in the form of information resources. The process of economic agents' interaction within the virtual integration plane is defined, which is determined by an important mechanism of implementation of the concept of integration development.

\section{References.}

1. Okunlola, O.A., Masade, E. O., Lukman, A. F., \& Abiodun, S. A. (2020). Investigating causal relationship between financial development indicators and economic growth: Toda and yamamoto approach. Iranian Economic Review, 24(1), 225-246. https://doi.org/10.22059/IER.2020.74480.

2. Korn, O., \& Schmidt, A. (2015).Gamification of business processes: re-designing work in production and service industry. Procedia Manufacturing, 3, 3424-3431. https://doi.org/10.1016/j. promfg.2015.07.616.

3. Davidavičienè, V., Aleliūnas, I., \& Sabaitytė, J. (2018). UROSAI ITWG model adoption for new IT audit framework: e-government cases. Naukovyi Visnyk Natsionalnoho Hirnychoho Universytetu, (2), 114-122. https://doi.org/10.29202/ nvngu/2018-2/14.

4. Ajibade, P., Ondari-Okemwa, E.M., \& Matlhako, M. (2019). Information technology integration for accelerated knowledge sharing practices: challenges and prospects for small and medium enterprises. Problems and Perspectives in Management, 17(4), 131-140. http://dx.doi.org/10.21511/ ppm.17(4).2019.11.

5. Petrasch, R., Boonyopakorn, P., Meesad, P., Sodsee, S., \& Unger, H. (2019). Data Integration Patterns in the Context of Enterprise Data Management, Recent Advances in Information and Communication Technology. Advances in Intelligent Systems and Computing, 936, 235-244. https://doi. org/10.1007/978-3-030-19861-9 23.

6. Heimburger, L., Buchweitz, L., Gouveia, R., \& Korn, O. (2020). Gamifying Onboarding: How to Increase Both Engagement and Integration of New Employees. Advances in Social and Occupational Ergonomics, AHFE 2019, Advances in Intelligent Systems and Computing, 970, 3-14. https://doi. org/10.1007/978-3-030-20145-6_1.

7. Nissen, V., Füßl, A., Werth, D., Gugler, K., \& Neu, C. (2019). On the current state of digital transformation in the German market for business consulting. In Nissen, V. (Ed.) (2019) Advances in Consulting Research, (pp. 317-339). Springer, Cham. https://doi.org/10.1007/978-3-319-95999-3 15.

8. Genc, T. S., \& De Giovanni, P. (2018). Closed-loop supply chain games with innovation-led lean programs and sustainability. International Journal of Production Economics, 440456. https://doi.org/10.1016/j.ijpe.2018.05.026.

9. Abtahi, A.-R., \& Abdi, F. (2018). Designing software as a service in cloud computing using quality function deployment.
International Journal of Enterprise Information Systems, 14(4), 16-27. https://doi.org/10.4018/IJEIS.2018.100102.

10. Heidari, M. R., Heravi, G., \& Esmaeeli, A. N. (2020). Integrating life-cycle assessment and life-cycle cost analysis to select sustainable pavement: A probabilistic model using managerial flexibilities. Journal of Cleaner Production, 254, 120046. https://doi.org/10.1016/j.jclepro.2020.120046.

11. Korn, O., Funk, M., \& Schmidt, A. (2015). Design approaches for the gamification of production environments: a study focusing on acceptance. Proceedings of the $8^{\text {th }} A C M$ International Conference on PErvasive Technologies Related to Assistive Environments PETRA, Proceedings, July 2015, (6), 1-7. https://doi.org/10.1145/2769493.

12. Bressanelli, G. (2019). Challenges in supply chain redesign for the Circular Economy: a literature review and a multiple case study. International Journal of Production Research, 57(23), 7395-7422. https://doi.org/10.1080/00207543.2018.15 $\underline{42176 .}$.

13. Glonti, V., Trynchuk, V., Khovrak, I., Mokhonko, G., Shkrobot, M., \& Manvelidze, L. (2020). Socialization of Organization Sustainable Development Based on the Principles of Corporate Social Responsibility. Montenegrin Journal of Economics, 16(1), 139-152. https://doi.org/10.14254/18005845/2018.14-4.8.

\section{Мультиагентна система інформаційного забезпечення управління інтеграційними процесами підприємств}

\section{А. А. Мазаракі, М. Г. Бойко, М. В. Босовська, М. В. Кулик}

Київський національний торговельно-економічний університет, м. Київ, Україна, e-mail: mazaraki_aa@knute.edu. ua; mboyko2006@ukr.net; bosovskam@ukr.net; kulikmariya@ ukr.net

Мета. Моделювання консолідованих інформаційних систем за результатами взаємодії економічних суб'єктів в інформаційному просторі. Обгрунтування інформаційно-комунікаційного спрямування віртуальної інтеграційної площини, принципів формування й сукупності елементів, що іії утворюють.

Методика. Теоретико-методологічною основою дослідження є неокласичні економічні теорії, концепції економічної інтеграції, системний і синергетичний підходи. Використані методи когнітивного моделювання для розроблення моделі мультиагентної інформаційної плошини реалізації механізмів взаємодії учасників в інтегрованих структурах бізнесу. На основі методу наукового пізнання сформульовані висновки щодо створення економіко-інформаційного простору взаємодії учасників економічної інтеграції.

Результати. Розвинуті теоретичні й методологічні положення щодо використання інформаційних технологій для забезпечення інформаційної взаємодії учасників інтеграційних утворень. Представлена модель мультиагентної інформаційної площини, в основу якої покладено 4-рівневу відкриту розподільчу інформаційну систему. Обгрунтована роль і завдання взаємопов'язаних підсистем в економіко-інформаційному просторі. Уточнені напрямки впливу через сформовані інформаційно-комунікаційні коридори. Доведена необхідність акумулювання інформаційних потоків у межах віртуальної інтеграційної площини на основі локальних інформаційних систем агентів. Удосконалена мультиагентна архітектура середовища віртуальної взаємодії суб'єктів підприємницької діяльності в межах інтеграційної площини; визначена схема моделі віртуальної взаємодії агента на основі віртуальної площини та удосконалена блок-схема 
алгоритму взаємодії економічних агентів у межах віртуальної інтеграційної площини.

Наукова новизна. Розвинута наукова позиція щодо пріоритетності забезпечення інформаційної взаємодії учасників інтеграційних утворень на основі використання інформаційних технологій. Розкрито інформаційно-комунікаційне спрямування віртуальної інтеграційної площини. Змістовно конкретизовано процес формування віртуального економіко-інформаційного простору взаємодії учасників у межах мультиагентної віртуальної інформаційної площини, що дозволяє здійснювати акумулювання, обробку, розподіл, використання консолідованої бази знань з метою інформаційного й комунікаційного забезпечення наскрізних бізнес-процесів, підтримки прийняття управлінських рішень для здійснення віртуальної взаємодії агентів.

Практична значимість. Запропоновано прикладний інструментарій модернізації інформаційних технологій для забезпечення інформаційної взаємодії учасників інтеграційних утворень. Сформована віртуальна інтеграційна площина для управління віртуальною інтеграційною взаємодією суб'єктів підприємницької діяльності та реалізацією концепції інтеграційного розвитку. Отримані результати дозволять здійснити інформаційну підтримку прийняття управлінських рішень, реалізовувати економічні зв'язки, проводити моніторинг реалізації інтеграційних програм і стратегій.

Ключові слова: інформаційні системи, інтеграційний розвиток, суб'єкти підприємницької діяльності

\section{Мультиагентная система информационного обеспечения управления интеграционными процессами предприятий}

\section{А. А. Мазараки, М. Г. Бойко, М. В. Босовская, М. В. Кулик}

Киевский национальный торгово-экономический университет, г. Киев, Украина, e-mail: mazaraki aa@knute.edu. ua; mboyko2006@ukr.net; bosovskam@ukr.net; kulikmariya@ ukr.net

Цель. Моделирование консолидированных информационных систем как результата взаимодействия экономических субъектов в информационном пространстве. Обоснование информационно-коммуникационного направления виртуальной интеграционной плоскости, определение принципов и совокупности элементов, которые ее образуют.

Методика. Теоретико-методологическую основу исследования сформировали неоклассические экономические теории, концепции экономической интеграции, системный и синергетический подходы. Использованы методы когнитивного моделирования для разработки модели мультиагентной информационной плоскости реализации механизмов взаимодействия участников в интегрированных структурах бизнеса. На основе метода научного познания сформулированы выводы по созданию экономико-информационного пространства взаимодействия участников экономической интеграции.

Результаты. Предложено направление развития теоретических и методологических положений по использованию информационных технологий для обеспечения информационного взаимодействия участников интеграционных образований. Представлена модель мультиагентной информационной плоскости, в основу которой положена 4-уровневая открытая распределительная информационная система. Обоснована роль и задачи взаимосвязанных подсистем в экономико-информационном пространстве. Уточнено направление влияния через сложившиеся информационно-коммуникационные коридоры. Доказана необходимость аккумулирования информационных потоков в рамках виртуальной интеграционной плоскости на основе локальных информационных систем агентов. Усовершенствована мультиагентная архитектура среды виртуального взаимодействия субъектов предпринимательской деятельности в пределах интеграционной плоскости; определена схема модели виртуального взаимодействия агента на основе виртуальной плоскости и усовершенствована блок-схема алгоритма взаимодействия экономических агентов в рамках виртуальной интеграционной плоскости.

Научная новизна. Представлена научная позиция приоритетности обеспечения информационного взаимодействия участников интеграционных образований на основе использования информационных технологий. Раскрыто информационно-коммуникационное направление виртуальной интеграционной плоскости. Содержательно конкретизирован процесс формирования виртуального экономико-информационного пространства взаимодействия участников в рамках мультиагентной виртуальной информационной плоскости, что позволяет осуществлять накопление, обработку, распределение, использование консолидированной базы знаний с целью информационного и коммуникационного обеспечения сквозных бизнес-процессов, поддержки принятия управленческих решений для осуществления виртуального взаимодействия агентов.

Практическая значимость. Предложен прикладной инструментарий модернизации информационных технологий для обеспечения информационного взаимодействия участников интеграционных образований. Сформирована виртуальная интеграционная плоскость для управления виртуальным интеграционным взаимодействием субъектов предпринимательской деятельности и реализацией концепции интеграционного развития. Полученные результаты позволят осуществить информационную поддержку принятия управленческих решений, реализовать экономические связи, проводить мониторинг реализации интеграционных программ и стратегий.

Ключевые слова: информационные системы, интеграиионное развитие, субъекты предпринимательской деятельности

Recommended for publication by N.I. Vedmid, Doctor of Economic Sciences. The manuscript was submitted 12.10.19. 